\title{
Los paisajes del yo reminiscente. Andrés Neuman, Eduardo Mendoza y Muñoz Molina ${ }^{1}$
}

\author{
The landscapes of the reminiscent self. \\ Andrés Neuman, Eduardo Mendoza y Muñoz Molina
}

\author{
MARÍA JOSÉ GARCÍA-RODRÍGUEZ \\ ${ }^{a}$ Universidad de Murcia, Facultad de Letras. España. \\ Correo electrónico: mariajose.garcia24@um.es
}

\begin{abstract}
El objetivo principal de este artículo es el estudio de las relaciones espaciotemporales como fórmulas de construcción de la consciencia discursiva. Para ello nos serviremos de tres novelas: Fractura de Andrés Neuman (2018), El rey recibe de Eduardo Mendoza (2018) y Ventanas de Manhattan de Muñoz Molina (2004). A partir del concepto de figuración, se han establecido dos ejes de análisis compartidos: la alienación de la mirada extranjera y la fabulación de la memoria. Sobre ellos se explicará el poder de resemantización espacial basada en dos dialécticas principales (dentro/fuera y presencia/ausencia) que recorren las tres obras. Así, a través de un análisis semiótico de la espacialidad, la desautomatización y dialogismo formalista y la reificación posmoderna quedarán evidenciadas como fórmulas estructurales y hermenéuticas que construyen los discursos personales de tres yoes reminiscentes.
\end{abstract}

Palabras claves: reminiscencia, memoria, extrañamiento, figuración.

This article aims to study the literary relationship between time and space as a narrative construction of discursive conscience. To that end, three novels have been analysed: Fractura by Andrés Neuman (2018), El rey recibe by Eduardo Mendoza, and Ventanas de Manhattan, by Muñoz Molina (2004). Embracing the concept of figuration, two main textual axis have been established, namely, the alienation of foreign view, and the fabulation of memory. Through those focuses the power of spatial resemantization is explained based on two essential dialectics (inside/out and presence/absence) that cross these three oeuvres. In doing so, the semiotic approach to spatiality has evidence how the formalist deautomatization and dialogism, together with postmodern reification have a meaningful impact on the structural and hermeneutics characteristics that create the personal discourses of three reminiscent selves.

Key words: reminiscence, memory, estrangement, figuration.

\footnotetext{
${ }^{1}$ Esta investigación se ha desarrollado bajo el programa Visiting Research Scholar Scheme de la School of Modern Languages de Cardiff University.
} 
Hay en la literatura y crítica contemporáneas un extendido interés por la narración personal de la (des)memoria como una corriente creativa que parece recoger y sobreponerse a las experimentaciones vanguardistas. Así lo demuestran las últimas aproximaciones teóricas que retoman las relaciones memoria y literatura desde muy distintos enfoques y ámbitos ${ }^{2}$ (Álvarez 2017; Colinas 2004; Colmeiro 2017; Díez 2005; Maldonado 2010; Nalbantian 2003; Young et al. 2008; etc.), junto a la persistencia de los estudios sobre las escrituras del yo y la autoficción que, desde el nacimiento del concepto con Dubrovsky (1977), buscan discernir entre un complejo entramado teórico que pone a prueba los límites y alcances de la referencialidad recogidos por Ana Casas (2012). Las tres novelas que ocupan este artículo, a saber, Fractura (2018), El rey recibe (2018) y Ventanas de Manhattan (2004) nos servirán para un estudio comparativo que contemple las relaciones intercontinentales de la literatura hispanoamericana actual a propósito de las problemáticas de la memoria y del yo ficcional, para lo que nos centraremos en las categorías esenciales que los sustentan: la comunicación entre el espacio y el tiempo discursivo. Veremos cómo Neuman, Mendoza y Muñoz Molina han creado tres textos que se definen por una voz narrativa personal acuciada por la indeterminación de su identidad, la cual queda reflejada en los desajustes del dialogismo ${ }^{3}$ que domina sus signos espaciotemporales como elementos desautomatizados e inscritos en una eterna cadena de asociaciones semióticas.

Cada uno de los textos aquí estudiados tiene como protagonista un personaje masculino enfrentado a su propia existencia: el seńor Watanabe (superviviente de las bombas de Hiroshima y Nagasaki), Rufo Batalla (hijo de la dictadura franquista) y un alter ego de Muñoz Molina (testigo del 11-S) son criaturas inscritas en un contexto determinado por las armas nucleares, las revoluciones occidentales de los 60 y 70, y el terrorismo. Los novelistas escogen acontecimientos trascendentales de la Historia reciente como latidos de fondo que marcan el ritmo de la historia de sus individuos en crisis; estos golpes a la identidad colectiva van conformando una revisitación del sujeto narrativo a su estar-en-el-mundo, dando a la consciencia que (se) narra el poder resemantizador de la subjetividad.

Los tres personajes recorren un espacio sobre el que proyectan su indeterminación y volubilidad individual: Tokio, París, Buenos Aires, Francia, Madrid, Barcelona... sirven de lugares de alienación a tres extranjeros que aparecen como contrapunto discursivo. Pero hay en todos ellos una ciudad común que los reúne y, más aún, que encarna el centro teórico que nutre tanto la especifidad como los vasos comunicantes de estos textos. $\mathrm{Me}$ refiero a Nueva York. La Gran Manzana ha jugado un papel metaficcional trascendental en el mundo del arte contemporáneo, convirtiendo a la ciudad misma en símbolo de la representatividad. Así lo explica el propio Muñoz Molina:

\footnotetext{
${ }^{2} \mathrm{Si}$ bien se advierte una prevalencia de las relaciones post-traumáticas, comunitarias o individuales que remiten a cambios socioculturales profundos, generalmente post-dictatoriales o bélicos.

${ }^{3}$ En términos bajtinianos de la palabra dialógica: "The word is born in a dialogue as a living rejoinder within it, and is shaped in dialogic interaction with an alien word that is already in the object. A word that is already in the object. A word forms a concept of its own object in a dialogic way" (Bajtín 1975: 279).
} 
Es que la ciudad en sí misma es el resultado de una invención; los que la fundaron estaban inventando un país, estaban inventando un mundo distinto al que habían dejado en Europa. Estados Unidos ha sido inventado en gran parte, ha cobrado la forma de la imaginación que la gente proyectaba sobre él (...) esas proyecciones, todo lo que la gente ha imaginado está allí de alguna manera. Entonces, tú vas caminando por una ciudad que es real pero que al mismo tiempo tiene un espesor de imaginaciones mayor que otros sitios porque ése es el lugar que mucha gente se ha imaginado. (2004b)

En su constitución como espacio, la presencia de la imagen de la Nueva York fantaseada es tan palpable que verla es recordarla: se recuerda desde el cine, las fotografías, los periódicos... se recuerda desde la literatura, la música y la pintura. El espacio neoyorkino se edifica en diálogo con la ciudad-imagen que lo precede, y así se despliega en estas novelas dicho phantasma, en términos platónicos, desde el que se reflexiona sobre la figuración. No hay más que advertir cómo la llegada de estos personajes se sustenta en la precipitación al re-conocimiento de los signos neoyorkinos:

Durante el trayecto desde el aeropuerto — que todos, inimaginablemente, seguían llamando Idlewild en lugar de Kennedy_ divisó al fin la silueta de aquella ciudad que para él sólo había sido un manojo de leyendas, fotografías y prejuicios. Ese cúmulo de imágenes previas le hizo sentir que, antes de verla, ya formaba parte de su pasado. Al contrario de lo que había supuesto, la visión de la Nueva York real le produjo un eco onírico, más ficcional que el de cualquier película. (Fractura 139)

Las grandes ciudades fueron concebidas para impresionar al forastero que llegaba por mar o, más tarde, en ferrocarril. (...) Ahora, por el contrario, los aeropuertos están lejos del centro, encerrados en sí mismos, de espaldas a la ciudad. (...) Estas circunstancias se agravan en el caso de Nueva York. El trayecto hasta la isla de Manhattan es pobre, triste y muy poco amistoso. (...) Después de un rato largo de zigzaguear por varias autopistas, al coronar una cuesta, apareció de repente el perfil imponente de Manhattan. Por haberlos visto infinidad de veces en imagen reconocí el Empire State, el Chrysler Building, la ONU. A tamaño natural parecían enormes. (El rey 99)

Buscas Roma en Roma, oh peregrino... Recién llegado a Nueva York, camino de la ciudad en un taxi, buscas Nueva York y te sorprende no encontrarla, y en el primer viaje te muerde por dentro la impaciencia de seguir avanzando y no haber llegado todavía. A lo lejos, inesperadamente, se ve no tanto una ciudad como el perfil quebrado y translúcido de un espejismo, delgados volúmenes verticales como lápices alineados de diversas alturas, ingrávidos (...). Con un sobresalto de la imaginación estás volviendo a descubrir lo que has visto muchas veces, estás viendo en la memoria y viviendo de nuevo en el presente la primera llegada, el arrebato y el asombro del primer viaje. (Ventanas 23) 
En definitiva, Nueva York emerge como un entramado de intertextos fraguados sobre ambos recuerdo y figuración para ser reconstruida en un juego de intercambios y confrontaciones discursivas. Es por ello que esta ciudad hiperboliza los mecanismos de simbiosis personajes-espacio establecidos por estos tres autores en estas literaturizaciones del yo reminiscente. Nueva York permite observar cómo estas novelas se rigen por la prevalencia de la impronta del ojo que mira sobre lo mirado gracias a la edificación de un espacio que, no solo acumula figuraciones de la consciencia individual, sino que va mutando en torno a un mecanismo de impostura cultural.

Antes de continuar con el análisis de las obras, merece que nos detengamos en esta noción de figuración desde la pretendemos ejecutar las teorías semiológicas sobre la rememoración. La noción de figuración deviene fundamental ya desde la caracterización de las novelas como narraciones personales; cada una con sus peculiaridades discursivas, son textos ficcionales enmarcados en lo que el profesor Pozuelo Yvancos $(2010 ; 2012)$ distinguió justamente como figuraciones del yo, acotando la indeterminación del término de autoficción. Si bien no es la problemática de las fronteras de las escrituras autobiográficas el objeto de nuestro análisis, dicho lugar teórico nos proporciona una de las claves que vertebran las novelas de Neuman, Mendoza y Muñoz Molina, y ciertamente del pensamiento literario en general: la literatura nacida de la figuración es un fenómeno estético que mediante la palabra recoge, más que la referencialidad, la impronta depositada en la imaginación de autor y lector. Estas voces del yo (que no deben confundirse con las expresiones autobiográficas) se nutren de la concepción del pensamiento literario como la dicotomía entre figuración y memoria, enunciada ya en Aristóteles como invención y reminiscencia.

Pese a la concreción de los signos de la Historia en estas tres obras, así como de las coincidencias biográficas de autores y personajes, la lectura de estos textos viene determinada por su naturaleza novelística; en consecuencia, partimos de una poética de la ficción consciente de que: "La semántica del lenguaje poético no se construye sobre el valor de la referencia, sino sobre 'figuras', imágenes, que permanecen indiferentes a la oposición verdadero/falso que rige los enunciados de realidad con valor de verdad del lenguaje referencial" (Pozuelo Yvancos 1993: 71). Ya hemos visto cómo el encuentro con el espacio neoyorkino ofrece al lector una mirada metaficcional en la que queda imbricada la reflexión sobre la escritura como un decir de la que podemos llamar memoria fabulada de la consciencia; a través de ese escenario pintado en la imaginación (que diría el Quijote ${ }^{4}$ ) se configura un sistema de signos capaces de evocar la ciudad-imagen, únicamente posible por ese ser figuración. En este sentido, el proceso de agotamiento de la escritura de la tantas veces repetida crisis de la novela establece un vínculo paralelo con el proceso de re-producción del simulacro de la ciudad de Nueva York; no hay más que citar lo que de ambas concluye Eduardo Mendoza: dice el catalán sobre el destino de la literatura, "hoy la ficción, debido a su agotamiento, se está empezando a imitar a sí misma y, por lo tanto, está perdiendo

\footnotetext{
${ }^{4}$ Así explica el hidalgo a Sancho el porqué de Dulcinea: "Y para concluir con todo, yo imagino que todo lo que
} digo es así, (...) y píntola en mi imaginación como la deseo” (I, 25: 286). 
fuerza" (en Pfeiffer 1999: 128-129); y en otro lugar escribe el catalán sobre Nueva York: "Al ponerse de moda, Nueva York ha empezado a imitarse a sí misma y abundan los fraudes" (1986: 12).

En suma, el proceso de figuración -entendido como aquel nacido de la dialéctica platónica y aristotélica de la phantasia, y recogida hábilmente para el estudio de las construcciones personales de la literatura por Pozuelo Yvancos (2010) - crea los cruces espaciotemporales por los que discurre la subjetividad del relato y, en consecuencia, la identidad del discurso narrativo. Considero que de dicho acto de figuración brotan los dos elementos esenciales que sostienen estas tres novelas y que podemos denominar de acuerdo a las dos condiciones espacio-tiempo: la mirada extranjera y la figuración de la memoria. A continuación expondremos las principales características extraídas de cada de estas categorías y que aunarán las consecuencias formales, estructurales y semióticas en cada uno de los autores.

Fractura, El rey recibe y Ventanas de Manhattan se sirven de voces narrativas personales que comparten el elemento axiológico sobre el que discurre la diégesis: la mirada extranjera. Una mirada que ejerce una fuerza de desautomatización y artificiosidad que marca la novelística actual y la naturaleza ficcional desde la institucionalización de lo fantástico que, como advirtió Cesare Segre ${ }^{5}$ haciendo uso de un concepto tomado de los formalistas rusos, hizo necesario un mecanismo de extrańamiento, que se ha visto pronunciado con la posmodernidad. Gracias a dicha posición de forastero, los espacios narrativos serán re-presentados y re-descubiertos a partir de las singularidades captadas por el ojo desacostumbrado y distante; una hipérbole de la finalidad del arte según Shklovsky (1925), que «no es la de acercar a nuestra comprensión la significación que ella contiene, sino la de crear una percepción particular del objeto, crear su visión y no su reconocimiento» (1970: 65). Dicho esto, si bien la estrategia narrativa de los tres autores deja revisiones comunes (de los depósitos de agua en las azoteas, de la actividad musical y, sobre todo, de la teatralidad de la ciudad de Manhattan), o quizá precisamente por estas similitudes, las tres voces del yo permiten ser analizadas desde las peculiaridades que las diferencian como miradas del extrañamiento.

Comenzando con la obra de Neuman, el personaje de Yoshie Watanabe queda, ya en su propio origen, situado en el espacio de exclusión, en Nagasaki, tierra de su infancia y sus olvidos, zona cero. Esta novela destaca por ser un crisol de voces narrativas que conforman, como diría Pozuelo Yvancos en su crítica, una novela coral que permite al autor "decir a Watanabe desde dentro y desde fuera" (2018a), una dicotomía que en realidad recorre toda la narración como una dialéctica interna (uchi/soto) estructural y discursiva. No solo por la alternancia de las voces que en primera y tercera persona van contando intermitentemente a Watanabe, también en la propia caracterización que organiza lo colectivo (dictadura/

\footnotetext{
${ }^{5}$ La institucionalización de las fuentes de lo fantástico "ha provocado que esa necesidad humana transforme la dimensión de lo cotidiano hasta promover una penetración de lo absurdo en la cotidianidad que adviene así extraña. (...) el nuevo modo de ficciones de Kafka que han subvertido la conciencia sobre la existencia humana y han llenado de absurdo los espacios más directamente reales y familiares" (Segre 1985: 23).
} 
democracia; guerra/paz) y del propio discurso de Yoshie (dulce/autoritario; serio/cómico); dialécticas que en último término responden al problema central de la novela (contar frente callar) y que quedará resuelto en el personaje como una dialéctica ontológica, anunciada por el juego que el personaje de Mariela hace con su nombre propio: reducido a Yo, en la expresión máxima del narcisismo, no hace sino buscarse en la voz ajena, definirse en el lenguaje ajeno, en este caso representado por un -She (Yo-she). El extrañamiento discursivo del protagonista, desarrollado en este caso por las voces narrativas que lo cuentan, viene marcado por el ostracismo cultural que excede las características intercontinentales de Mendoza y Muñoz Molina gracias a la ininteligibilidad de Oriente en Occidente; más aún, Watanabe se convierte en su propia figuración con la adopción de cada variedad idiomática, consciente de su construcción de sujeto a través la actualización del lenguaje: "con el cambio de lengua había vuelto a mudar de piel" (Fractura 159). Esta percepción lingüística comunica entonces con una prevalencia literaria que acompaña al japonés durante todo el viaje: Chéjov, quien "entre el trabajo, la salud y las dudas, nunca estuvo muy seguro de dónde instalarse. Sus historias parecen contadas desde esa indefinición, como si la costumbre de mirar en todas direcciones le hubiera permitido adoptar cualquier punto de vista" (Fractura 159).

En suma, el lenguaje se convierte en el principal foco de reflexión para la alienación de Watanabe, siempre construido en los huecos (resuenan las bombas estadounidenses) de la ambigüedad semántica. Las interferencias lingüísticas vienen a comportarse como huecos de un discurso intuitivo, como advirtiera Lorrie, con el que se define su ser-extranjero. El lector se sume en esta otra fractura, la interpretativa, que acaba por construir al personaje como una perpetua figuración de sus interlocutoras; incluso, aquella tercera persona que nos enseña al Watanabe ya anciano en Tokio no deja de contarnos al personaje en su ensimismada (en sentido literal del término) intimidad. Esa cultura binaria atestiguada por propio el narrador se ejecuta así en la dualidad del decir y el callar que, gracias a la insistencia del acto de traducir, hace palpable la búsqueda de un lenguaje que permita explicar el relato, encontrar el decir del hibakusha. De hecho, la inclusión del personaje de Mariela, intérprete argentina, permite al autor evidenciar el papel de la conversión lingüística como una re-presentación identitaria forzada por la presencia del sujeto ajeno: "Supongo que en eso consiste la traducción, ¿no? En contar una parte de tu identidad con el pretexto de un extraño" (Fractura 184).

$\mathrm{Al}$ ostracismo constante al que se somete el japonés se suma la ambigüedad por la que parece escapar el discurso, y con ello la identidad, de Watanabe, solamente intuida de entre el entramado de fragmentos narrativos que nos dirigen sus amantes. He aquí que se incluye parte de la letra de Leonard Cohen (retomando la trascendencia de la cultura norteamericana en la diégesis del yo) que en este contexto recoge el que creo es el núcleo de esta novela: There is a crack in everything, that's how the light gets in. La idea que venimos defendiendo del espacio de la ambigüedad en la fractura idiomática se traslada a la música occidental que, a su vez, queda engarzada con la cultura japonesa de las contradicciones

\footnotetext{
${ }^{6}$ Remito a la teoría de los actos de habla de Pratt (1986) en la que el sujeto se constituye en el lenguaje: "In either view, authorship is no more, and no less, than another of the many ways a subject through speech" (64).
} 
zen $\mathrm{y}$, en especial, del kintsugi; es precisamente el espacio de la fractura aquello que da sentido a la entidad, lo que la ilumina y ańade valor ${ }^{7}$. Por ello, el extrańamiento de esta figuración del yo japonesa se concentra en el contraste interlingüístico, evidenciado como piezas discursivas de un relato que se cuenta por los silencios.

De otro lado, la reiterada adopción de lenguajes culturales de Yoshie hiperboliza una desautomatización semiológica mediante una imitación que revela simultáneamente la distancia idiomática y los procesos de construcción simbólica en su valor social; así ocurre por ejemplo en su acoplamiento a la comunidad negra de Harlem.

Cuando salíamos a hacer cualquier cosa, él siempre terminaba presentándome a alguien. Utilizaba el slang afro para entrar en confianza. Si veía a una niña por la calle, por ejemplo, era capaz de decirle: Isn't it a bit late for a beauty like ya, honeychild? Y la niña decía: You ain't got to worry, sir, I'm a big girl. Y él contestaba: You ain't no bigger than a minute, honeychild! (Fractura 125).

Sus esfuerzos miméticos de adaptación acaban por resolverse en una palpable duplicidad del que es y no es, del que está y no está; una sobreactuación artificiosa de la naturalidad lingüística. Esta dialéctica cultural es la que define al espacio neoyorkino como una imparable revalorización de sus barrios, destacada por las tres novelas; una progresiva reificación social donde los símbolos culturales se neutralizan en una momificación, como aquí la llama el personaje de Lorrie, con sus restaurantes afro-fusión que van vaciando y desplazando la significación de los discursos culturales que la pueblan. "Acaso exista algún vínculo, reflexiona Watanabe, entre humanizar a una bomba y deshumanizar a una población" (Fractura 65).

Esta exposición de los signos motivados (Barthes 1986), ofrecidos en su relatividad y reificación, ha sido precisamente uno de los focos de atención desde el nacimiento de las teorías de la posmodernidad (Baudrillard 1978; Jameson 1991). El agotamiento que va ahuecando el lenguaje hasta convertirlo en simulacro o pastiche es precisamente lo que, bajo su mirada cómica, evidencia Eduardo Mendoza en El rey recibe a través de su característica perspectiva ex-céntrica ${ }^{8}$. Continuando con la presencia de ese personaje que vaga en busca de su sitio en el mundo sin llegar a encontrarlo (que aquí llega a personalizarse en la hipertrófica figura de intercalada del Rey errante y su Estado de bolsillo), lo que proporciona

\footnotetext{
${ }^{7}$ Igualmente, los huecos comunicativos colmados por esa figuración incierta de sus amantes, será la ambigüedad con lo que se definía Yoshie: al perder la alienación idiomática y reducir así la ambigüedad comunicativa (esto es, la necesidad de figurarse), la personalidad del japonés perdía su identidad para todas ellas; lo que corresponde a su vez con la relación del propio Yoshie con la sexualidad y las elipsis del erotismo pornográfico.

${ }^{8}$ Tanto es así que, pese a la versatilidad de su obra, el quehacer literario de este autor se sostiene por la siempre desarraigada perspectiva de sus narradores. Así lo destaca la crítica: "Lo más «mendocino" de la novela es la elección de un personaje, Rufo Batalla, que implica un modo de ser extraterritorial. (...) nada compromete al personaje, quien se parece bastante a un Bartleby, al que le pasan cosas que no termina de entender del todo" (Pozuelo Yvancos 2018b).
} 
la singularidad al personaje de Rufo Batalla es la distancia irónica sobre la que observa y se observa. Pese a la voz narrativa única de la primera persona, Mendoza alcanza el privilegio de la perspectiva descontextualizada gracias a la orquesta de discursos que interactúan con el personaje, lo que en su caso permite percibir el mundo como un artificio mimético obstinado por re-presentarse. Este es sin duda uno de los logros de la posmodernidad narrativa del autor, y sin embargo apenas estudiado: el extrañamiento estético (heredero del formalismo) que concede un personaje como Rufo Batalla lleva la mirada mendocina a un lugar discreto desde el que estudiar las paradojas de los grandes movimientos socioculturales, para señalar su textualidad en sus desajustes.

Así queda patente en sus encuentros con la otredad, a la que accede casi como voyeur, donde Rufo es una figura textimonial a la que el discurso ajeno viene a mirarse: es en él donde encuentran un lugar de justificación y a través de su alienación se ejecuta una desautomatización del discurso que oficialmente representan y les representa. En su funcionalidad narrativa, Rufo es requerido por la narración por su ser-extranjero; tomemos de ejemplo su asistencia a la liberación homosexual tras los disturbios en Stonewall, cuando el protagonista charla con un profesor de filosofía retirado en uno de los locales de Greenwich Village:

- ¿Qué le parece?

- Me parece muy bien, por supuesto.

- No me refiero a mi conducta, sino a esto.

-No sabría decirle, yo no soy gay.

- Salta a la vista, por eso se lo pregunto. (El rey 235)

Detrás de estas conversaciones se esconde un extrañamiento de la signicidad que, junto a la transitividad de lo histórico, revela el proceso de figuración que hay detrás de todo lenguaje inserto en la narración mendocina. La búsqueda por lo absoluto de cada uno de los códigos queda desautomatizada gracias a la progresiva cosificación de un discurso que será imagen-de-discurso, imagen hiperbólica fundada sobre las consecuencias de la mirada turística que las compone y deforma. Es por ello que esta búsqueda del yo en Mendoza comparte con la novela de Neuman la ausencia de una identidad auténtica en una ciudad construida sobre fronteras y una sociedad en un momento de redefinición. Pero es ante los ojos de Rufo cuando el ostracismo se extiende al conjunto de caracteres novelescos; la disidencia discursiva se superpone a la imagen figurada como una apertura desautomatizadora y, sin embargo, lo turístico se impone como valor semiológico que hace de la asimilación mimética una necesidad, por lo que el mundo narrativo habitado por Rufo se colma de imposturas discursivas pactadas:

La adaptación es un mecanismo de subsistencia. (...) este vecino (un indio americano: cheyenne, cherokee, sioux, da lo mismo), un día, hablando, me contó que, de nińo, cuando veía películas del Oeste, ya sabía que los buenos eran los cowboys o los soldados o los de la diligencia, y que los malos eran los indios. 
Naturalmente, él iba a favor de los buenos. Si lo pensaba, le parecía un poco raro, pero hacía como si fuera normal, porque la alternativa era quedarse sin ir al cine los fines de semana. (El rey 227)

Este es un momento significativo de la novela en el que a través del discurso de un personaje de la marginalidad, Ernie, extranjero y homosexual, se ilumina la colección de imágenes figuradas que, convertidas en simulacro estético, acaban dominando la construcción del discurso individual y colectivo?. Más allá de los desajustes semióticos, es la fragilidad pragmática del lenguaje cultural la que define a este texto: el pacto de verosimilitud del que depende el reconocimiento entre emisor y receptor queda al descubierto, y el discurso oficial se revela finalmente simulacro vacío; desde el comunismo en Checoslovaquia, el franquismo en Espańa y la solidez del sistema estadounidense, hasta el arte de vanguardias, la liberación de la mujer o la identidad nacional son contados como pantomimas sostenidas sobre el disimulo y la complicidad de sus figurantes. La exhibición como figuración del otro (y para el otro) es la herramienta comunicativa posmoderna por excelencia. Así como las teorías conversacionales se detienen en las modulaciones hermenéuticas para la comunicación feliz, el mundo narrativo de Mendoza es un diálogo consciente fundado en lo espectacular como expresión del signo y revelador de su inestabilidad en todas las esferas de la novela.

No es baladí que, previa a su mudanza a Nueva York, el protagonista asegure: "Algo estaba cambiando, y para mí Sgt. Pepper's Lonely Hearts Club Band había sido el detonante de aquel cambio" (El rey 87); recordemos es este el disco en el que los Beatles responden ante la histeria mitómana de su imagen e idean una banda ficticia que les permite dejar a un lado su identidad musical y experimentar desde la figuración de ese Sargento Pimienta. Las relaciones que los sujetos entablan con la ciudad se concretan así en la definición misma del proceso de creación literaria; el autor se finge otro(s), experimenta con las posibilidades ficcionales y discursivas como artificio. Aquel detonante musical es en realidad la sinécdoque que activa el funcionamiento novelístico mendocino: a nivel narrativo, será esta ciudad-imagen sobre la que el individuo puede representarse, figurarse desde el anonimato concedido por el espacio neoyorkino.

"No soy nadie aquí, o soy un Don Nadie, y sin embargo soy más yo mismo que nunca, más que en cualquier otra parte" (Ventanas 341). Son estas las palabras de la tercera de nuestras consciencias del desarraigo. Si el estilo de Rufo Batalla se sustenta en la distancia irónica y las voces de Neuman lo hacían en su fragmentarismo helicoidal, el relato de Muñoz Molina se sostiene en un discurrir figurado, una exploración de las posibilidades discursivas que se filtra a la estructura profunda de esta tercera novela que nos ocupa. Ventanas de Manhattan, ya desde cuyo título se intuye la importancia de los ojos que miran Nueva York y las posiciones desde dónde la miran, se construye como una escritura desatada que se asoma a las infinitas aberturas desde las que (se) observa el narrador: cuadros de Hopper, fotografías de Richard Avedon, puertas, mirillas y ventanales de hoteles, de

\footnotetext{
${ }^{9}$ Precisamente pronunciadas en Little Italy, espacio donde la mafia ya es atracción turística.
} 
aviones, de oficinas, de hogares, de Hitchcock. La voz personal que elabora Muñoz Molina discurre sobre una escritura divergente propia de la mirada errabunda estudiada por Alexis Grohmann (2011), capaz de aunar una textura intertextual gracias a su fluir figurativo.

Los matices que distinguen la desautomatización del extrañamiento son los que singularizan a esta novela: no es la alienación del yo frente al otro el movimiento que define este discurso; el narrador de Ventanas utiliza su mirada extranjera para desautomatizar la trivialidad de lo habitual, contando lo cotidiano desde el mundo extraordinario de lo sensible. Con una narración más introspectiva que las dos anteriores, la voz narrativa de esta novela es el desarrollo de su propio mirar y su caminar, un texto estructurado en vistazos o paseos que continúan haciendo patente la sucesión de fronteras culturales neoyorkinas como museos semióticos de muy distintos agentes sociales: "un corte geológico que atraviesa mundos sucesivos, provocándole al transeúnte no habituado al asombro de tan caprichosa variedad como un mareo de rotaciones planetarias, un vértigo de niño en el tiovivo que ve moverse con demasiada rapidez las caras y luces de la feria" (Ventanas 22). De nuevo la consciencia del relato se concentra en los contrastes espaciales de la pertenencia, del dentro y fuera (más cercano y, por ello, más amplificado que nunca) que marcan el lugar desde donde (se) mira.

Dentro del universo de colores y sonidos creado por Muńoz Molina, la individualidad aparece como una de las principales preocupaciones narrativas. El acto de figurarse — en el espacio (Mendoza) o en el idioma (Neuman) — se convierte aquí en un viaje hacia las posibles rutas tomadas y no tomadas por el sujeto, con una consiguiente multiplicación de identidades discursivas posibles que hacen de él una acumulación de sus phantasmata. La ya expuesta dualidad del extranjero que bailaba entre lenguajes y entre comunidades, negándose siempre a sí mismo, se manifiesta aquí en el extrañamiento de la propia existencia, vista igualmente como una ruta, representada desde fuera, desde lo que no fue, es o será:

cuando uno si ha sido algo afortunado (...) puede sentir que ha logrado algo sólido, estable, (...) entonces descubre que lo que ha logrado no es gran cosa, si lo mide con las posibilidades que intuía dentro de sí mismo, y que por cada vida posible que se cumple, cada deseo que se satisface, hay otras vidas que no se llegaron a vivir, otros lugares que no se han conocido, y también que el tiempo no es ilimitado, de modo que hacer algo es sobre todo dejar de hacer otra cosa. (Ventanas 264)

Muñoz Molina hace patente en esta novela el triunfo absoluto e inalcanzable de la figuración, que siempre nos señalará la paradoja del ser y no ser, estar y no estar. Es en este punto cuando se comprende la importancia de los espacios de la representatividad recorridos por esta consciencia narrativa; dentro del macrocosmos neoyorkino, el museo (en un amplio sentido del término, un sentido posmoderno si se quiere, que abarca cualquier escenario de exposición) aparece como el lugar predilecto de la novela, pues es en él donde los objetos se convierten en signos. El museo es el contexto explícito de la semioticidad, en el que concurren las huellas últimas, los restos materiales, del discurso figurado que les une 
a su historia. Los objetos expuestos en el Tenement Museum, en el de Historia Natural o en el Metropolitan se unirán a aquellos del Rastro o a los atesorados por algún sintecho, armando un universo de enclaves cronotópicos para la figuración de la voz narrativa. El espacio neoyorkino es capaz de convertir cualquier objeto en producto, así como el museo los convierte en reliquia. Hay un extrańamiento de los objetos, alienados de su contexto y, en ese sentido, el espacio neoyorkino es el gran bazar del mundo y el narrador el coleccionista ${ }^{10}$ que atesora asociaciones encontradas por la mirada desautomatizadora de colores, olores y sonidos; pero también de presentes, pasados y futuros hipotéticos, que se combinan en un discurrir literario nutrido por la memoria y la invención.

No es, por tanto, la dialéctica que incorpora el personaje de Watanabe en su función literaria del doble, ni la parodia que traza Rufo sobre lo que Greenblatt (1992) entiende por economía simbólica: la resemantización ejecutada por el discurso de Muñoz Molina nace de su prioridad por el universo de lo sensible y su manipulación de los objetos espaciales como elementos que contienen el tiempo. El discurso del yo se convierte en el espacio de la praxis, como aquel brote esquizofrénico del pastiche de Jameson (1991) mediante el que se explora la cadena de significación liberada en una nueva vivacidad por la ruptura temporal ${ }^{11}$. De tal manera que las colecciones de objetos que el yo de Ventanas de Manhattan va recogiendo como detonantes del relato conforman un universo de presencias reales que evocan ${ }^{12}$ textos ausentes, impresiones de una ciudad que vuelve a ser reconstruida desde la figuración, esta vez, instalada en el tiempo.

Este poder evocador de la figuración capaz de romper la temporalidad es el que nos lleva al segundo de los elementos arriba enunciado como esencial para los tres novelistas: la figuración de la memoria. Las miradas narrativas por las que se conforman Yoshie Watanabe, Rufo Batalla y la voz de Muñoz Molina buscan si no resolver, sí recorrer los entresijos de la problemática de la eikon formulada por Paul Ricoeur (2003) en su estudio sobre la memoria, la historia y el olvido. La dialéctica del yo-otro que establece las fronteras desde las que se cuentan y se callan los lenguajes culturales se proyecta ahora sobre los juegos de recuerdo y olvido gracias al juego de la presencia y ausencia; una conexión de la figuración y la memoria que no deja de advertir Pozuelo Yvancos (2012).

Las distintas exploraciones del yo alienado y su dialéctica espacial convergen aquí en un centro común que hermana a los tres textos como viajes, no solo en el espacio, sino

\footnotetext{
${ }^{10}$ Para un estudio del fenómeno del narrador coleccionista y sus vínculos con la posmodernidad y las épocas de cambio, ver Sánchez (1999).

11 "La ruptura de la temporalidad libera súbitamente este presente temporal de todas las actividades e intencionalidades que lo llenan y hacen de él un espacio para la praxis; aislado de este modo, el presente envuelve de pronto al sujeto con una indescriptible vivacidad" (Jameson 1991: 66).

${ }^{12}$ Es interesante traer a colación la definición que la RAE ofrece de 'evocar': 'Recordar algo o a alguien, o traerlos a la memoria'; 'Dicho de una cosa: Traer algo a la imaginación por asociación de ideas'; y 'Llamar a un espíritu o a un muerto'. Tres acciones que marcan explícitamente el flujo discursivo del narrador de Muñoz Molina, e igualmente desarrolladas por Mendoza y Neuman.
} 
en el tiempo. Decía Bergson (1896): "Para evocar el pasado en forma de imágenes hay que poder abstraerse de la acción presente, hay que saber otorgar el valor a lo inútil, hay que querer soñar. Quizás, sólo el hombre es capaz de un esfuerzo de ese tipo" (2006: 86). A tal efecto, la escritura se revela lenguaje figurado de la memoria, una memoria histórica, pero también de la subjetividad textual, artística y sensible.

Siguiendo con Ventanas de Manhattan, en ella los intertextos trenzados en el caminar narrativo funcionan como pulsiones que van configurando Nueva York como una impronta oprimida en la imaginación por la literatura, el cine pero, especialmente: la pintura y la música.

Me acuerdo de la perfección estática del cuadro de Seurat, y del musical que le dedicó Stephen Sondheim, Sunday in the park with George: la maravilla de un instante supremo que parece detenido en un éxtasis de culminación y de azar y el deseo imposible de atraparlo, de que no se pierda en el flujo del tiempo, la necesidad de fijarlo en un lienzo o en una fotografía precisamente porque se sabe que el tiempo se lo llevará, que va a empezar a volverse borroso en la memoria en cuanto apartemos de él los ojos. (Ventanas 165)

La razón de ser de la insistencia en estas dos últimas formas artísticas se ha de buscar en su diferente relación con la temporalidad: la perfecta eternidad de la imagen inamovible del pasado frente a la fugacidad de las notas que escapan por el aire en el presente huidizo. Es esta la dicotomía que marca el tempo de la narración de Muñoz Molina, siendo ella misma una lucha constante por atrapar la inmediatez de entre la eterna fugacidad. Al uso de una poética cercana al lirismo como arma proporcionada a esta lucha de la diégesis, se le une el protagonismo de otro lenguaje que persigue la significación del tiempo: el periodístico. Los medios de comunicación (prensa, radio y televisión) acuden a este relatar el presente neoyorkino hundido en la inverosimilitud del 11-S. Las oquedades que contradicen la solidez implacable de las torres necesitan ser explicadas desde la alienación de la pantalla o el papel que permiten concretar, si quiera como representaciones, la ininteligible mutación de lo estable y su derrumbamiento, de la eternidad en fugacidad inaprensible.

En el intercambio del presente con el acontecer histórico, el periodismo se convierte en testigo a dos tiempos, relator y testimonial, dando muestra de las variaciones hermenéuticas con las que se crean y manipulan los signos en su diacronía. Nos permitimos pese a su longitud, reproducir la sucesión de estas dos posiciones alternas recogidas por el yo narrativo de Muñoz Molina, pues en ellas se sintetizan de una forma muy significativa la dialéctica temporal que interviene en la materialidad o representatividad del acontecimiento, siempre atendido como una figuración, aunque desde sentidos narrativos muy diferentes:

Hace falta un esfuerzo de la memoria para recobrar el instante en que se vieron por primera vez esas imágenes, que a lo largo de las horas de ese día y en los meses y años futuros se van a repetir tanto que acabará embotándose su cualidad apocalíptica, 
su impacto sísmico sobre la imaginación. Las torres ardiendo, derrumbándose como torpes maquetas en una película japonesa de catástrofes, se convertirán velozmente en símbolos, en alegorías banales y retóricas, se multiplicarán en revistas, en primeras páginas de diarios con titulares enormes en caracteres de todas las escrituras posibles, en portadas de libros, en camisetas y souvenirs turísticos. Ahora, sin embargo, en esta mañana de martes, en la pantalla del televisor, el choque de los aviones, el fuego y la caída lenta de las torres, las voces de los locutores alteradas por el desconcierto y el pánico, son un hecho absoluto, un trastorno inconcebible del orden natural de las cosas (...). Pero al mismo tiempo lo que percibe uno, casi más fuerte que el estupor, es una sensación muy fuerte de irrealidad, como de distancia hacia lo que está viendo con los ojos, lo que se repite idéntico si cambia de canal en el televisor o conecta la radio, encontrando en ella el mismo fragor de desastre, las mismas voces que no aciertan a saber ni a contar que es de verdad lo que está pasando. Porque fuera del televisor y de las voces de la radio las cosas habituales no se han modificado, como enquistadas en una neutral normalidad. (Ventanas 59-60)

La trascendencia del periodismo en la construcción temporal del relato de la crisis existencial queda asimismo reflejada en la novela de Eduardo Mendoza. "Periodismo es todo lo que será menos importante mańana que hoy" (El rey 36). Rufo Batalla comienza así como periodista accidental, impregnando a la novela de esta forma de reconstrucción semiológica de la 'historicidad' que da especial protagonismo a la prensa como el lenguaje de la contemporaneidad. Siendo reportero de una revista rosa, constructor (e inventor literal) de mitos locales, Rufo inicia un juego en apariencia intrascendente sobre la fabulación periodística que se sin embargo extenderá hacia un perpetuo espectáculo histórico personalizado más tarde en Watergate. De hecho, Mendoza logra aunar magistralmente los dos elementos que circundan nuestro análisis en una figura histórica: la presentación de Fraga como doble ministro de Información y Turismo. Dos ministerios aparentemente inconexos que el autor logra evidenciar como dos caras de la misma moneda ${ }^{13}$ : el periodismo representa el lenguaje del cambio controlado, el turismo la posibilidad de encontrarse ante el otro.

Dejando a un lado la anteriormente expuesta narración ante el sujeto alienado, el periodismo deviene fundamental como fórmula de construcción de la memoria limitada por el presente, cuya distancia de la significación futura permite a Mendoza jugar con la semántica historicista. El periodismo es aplicado como fuerza desestabilizadora que señala las consecuencias hermenéuticas a partir de la resemantización de lo histórico frente a lo anecdótico; una idea que, de hecho, recorre el texto y lo señala como memoria haciéndose, fabulándose, bajo la mirada de Rufo:

\footnotetext{
${ }^{13}$ A pesar de la represión del Régimen, España abría nuevos ángulos de visión, el turismo franqueaba las fronteras y se aliviaba tímidamente la censura, un acontecimiento que Mendoza lee hábilmente en el lenguaje la reificación lingüística del eslogan (Spain is different); fundado sobre una mirada turística, sirve a la proyección de una imagen distintiva en el encuentro con el otro y con la individualidad.
} 
La cosa es que cuando uno mira hacia atrás se acaba dando cuenta de que muchos de los acontecimientos que en su día le parecieron anecdóticos han acabado por convertirse en acontecimientos históricos que han marcado el presente, y que muchos otros acontecimientos vividos como históricos, han pasado a ser simples anécdotas. (Mendoza 2018b)

Eduardo Mendoza insiste en el sentido 'histórico', en la mutabilidad paradójica de la valoración de los episodios en virtud de las distancias desde las que se miran. Pero lo que me interesa destacar en este punto es cómo esa consciencia subjetiva del yo narrativo sirve al autor para una figuración, no de un alter ego en Rufo Batalla (como buena parte de la crítica ha querido ver), sino de su propio quehacer literario anclado en la memoria de sus lecturas y escrituras. Esta abierta voluntad de caminar por los lugares de la figuración, que guardan la imagen del pasado como una colección de lo paradigmático — y no de lo verdadero-, no solamente afecta a la revisión de los acontecimientos históricos, sino textuales. Desde la propia estructura, la novela se ofrece como textimonio fabulado, como la directa presentación de la idea de la infancia recuperada de Savater (2017), siempre presente en nuestro autor: interferencias textuales que parecen responder a impulsos del subconsciente mendocino, recuerdos fugaces, como impresiones sin identificar, sin ordenar ni clasificar: una liberación intermitente de lecturas figuradas que se acoplan a la narración ${ }^{14}$.

No hay más que recordar la primera y la última de todas las citas incorporadas para ilustrar esta memoria textual híbrida y fragmentaria que nos ofrece Mendoza, lugares textuales de significación, también resemantizada desde la lectura; aunque como decíamos sin identificar, son extraídas respectivamente de Tarzán de los monos: "I had this story from one who had no business to tell it to me, or to any other" (El rey 6), adentrándose en el re-contar intertextual; y de Pedro Páramo: "Los vientos siguieron soplando todos esos días. Esos vientos que habían traído las lluvias. La lluvia se había ido; pero el viento se quedó" (El rey 357). Esta última referencia cierra con ese irse y quedarse como el movimiento que ha columpiado toda la narración, cuya metáfora metereológica viene a consolidar el inmovilismo de la muerte en el viento que se queda en el páramo, frente a la huida de la lluvia que fecunda la vida. Nótese además la peculiar asociación evocada entre los textos con el nombre del protagonista Rufo, evidente deformación de Juan Rulfo, que lo conecta abiertamente (y se comprueba en esa última referencia) a la fábula onírica de la memoria de muertos y vivos, de la búsqueda de la identidad, del totalitarismo y de los vínculos heredados que constituyen Comala.

\footnotetext{
${ }^{14}$ La diversidad de las fuentes es abrumadora: Emerson, Montesquieu, Miguel Costa i Llobera, Montaigne, Bernardino de Sahagún, Richma Crompton, Samuel Johnson, W.H. Auden, Joseph Maréchal, Donald Barthelme, Valle-Inclán, Joyce, Luys Santa Marina, Baudelaire, Sterne, Gautier, Lewis Carroll, Javier Marías, Rider Haggard, Jane Austen, Stevenson, Tennessee Williams, Chandler, Goethe, Maurice Leblanc, T.S. Eliot, Moliere, Unamuno, Baroja, Camus... Además de eslóganes, como el de amnistía postfranquista, proclamas religiosas, villancicos; una hipertrofia del desorden descatalogado de voces referenciales a las que desde su primera novela acude Mendoza.
} 
Se observa por tanto cómo la figuración de la memoria excede el plano del acontecer histórico para situarse en la dimensión subjetiva del yo, incluyendo en su institución una permeable y fragmentaria recolección de objetos, imágenes y textos como improntas grabadas en las tablas regaladas por Mnemósine. A estas planchas platónicas parece aludir precisamente Andrés Neuman. De las tres novelas, la de Neuman es quizás en la que con mayor evidencia la problemática de la figuración de la memoria es llevada a la superficie de la narración. Sin ir más lejos, así lo anuncia el primer capítulo "Placas de la memoria". La novela arranca con una ruptura del espacio-tiempo basada en la dialéctica presencia/ausencia de toda figuración: la visión de los objetos ausentes los vuelve "burlonamente nítidos" ante Watanabe. Y enseguida, el relato del seísmo completa la problemática anecdótica: "Un terremoto fractura el presente, quiebra la perspectiva, remueve las placas de la memoria (...) el mundo oscila ligeramente, cada cosa emite el recuerdo de su inestabilidad" (Fractura 10-11). ¿Es la historia un pedazo de la ciencia sísmica? Con esta pregunta el narrador de Neuman nos sumerge en las asociaciones semiológicas de una fractura que recorría la identidad de ese yo extranjero, y que ahora dominará también el discurso de la memoria como el lenguaje de la huella. Encontramos un diálogo con el coleccionismo narrativo de Muñoz Molina, y desde él se puede advertir la significativa aplicación de Neuman pues, más que objetos, su narración colecciona huecos. Partiendo de Hiroskima y Nagasaki, lugares que solo serán su propia cicatriz, el valor de los elementos espaciales está dirigido por Watanabe hacia su huella, hacia el vacío de su ausencia ${ }^{15}$ : solo podrán figurarse desde la resta. "Quizás la elocuencia de los restos consista en eso, en la necesidad de completar lo que se ve. En deshacer la resta" (Fractura 215).

Así como Watanabe lo es en sus silencios, la memoria funciona en este texto por sus olvidos. Más que la reminiscencia, Neuman explora la desmemoria defensiva, la voluntad que se impone al individuo de olvidar, esto es, de no contar. La posición del protagonista como sujeto de la memoria va cambiando; su silencio sepulcral parisino, pasa a la dialéctica neoyorkina, a una argumentación del eludir y el mencionar acuciada por la conciencia de la elipsis discursiva del periodismo de Lorrie. A esta etapa sobrevendrá la necesidad de transmisión de su discurso argentino, con el hijo de Mariela, y la insistencia reiterada del yo madrileño, que se agota en Carmen y su indisposición a seguir escuchando.

Pero pese a esta sucesión narratológica, la temporalidad sobre la que viaja la consciencia de Watanabe es, como adelantábamos al principio, un movimiento helicoidal. Las distintas etapas vitales que rememoran cada una de las amantes del protagonista se revelan en conjunto como una espiral cuya circularidad se reitera puntos comunes del viaje de Yoshie, siempre hacia su propio origen. "El mundo entero solía reducir aquel lugar a su destrucción. Bastaba nombrarlo para que la bomba volviese a caer, en un rebobinado sin fin" (Fractura 144). Esta eterna circularidad del espacio se evidencia en la personalización

\footnotetext{
${ }^{15} \mathrm{Ni}$ siquiera en su colección de banjos, donde se juega a la anulación de la música por su contemplación figurada: "Se pasaba horas afinándolos. Si no los afinas, sufren, me decía. El que sufría era él, por supuesto. Cada vez que los miraba en silencio, se imaginaba un concierto de instrumentos desafinados" (Fractura 40).
} 
de la identidad de Yoshie como último representante de toda una generación, viviendo el nacimiento de una nueva en Fukushima, lo que confirma la idea del pasado absoluto japonés y de "la repetición de las tragedias, o en las tragedias como repetición" (Fractura 159).

En su último viaje a Fukushima, un progresivo descenso hacia los orígenes de la tragedia, la circularidad temporal se instala definitivamente gracias a la textualidad. A cada paso por las zonas de control, nos aproximamos al centro del espacio de exclusión. En cada una de las fronteras que marcan las sucesivamente invisibles circunferencias de radiación, Yoshie Watanabe deposita los relatos individuales que van trenzando el acceso a su propio epicentro narrativo. Contando sus historias, construye su propio discurso. La escritura de su memoria se convierte en el ensamblaje de los testimonios pasados y presentes, propios y ajenos, referenciales y figurados, siendo todos ellos una indivisible acumulación de silencios y palabras que conforman el relato folklórico de una tragedia universal.

En conclusión, el discurso de estos narradores deja entrever una persecución de las huellas de sus pisadas en el mundo. Posicionados desde el principio en un lugar desplazado, en un exilio voluntario que marca su mirada, siempre extrańa, el narrador adquiere conciencia de sí mismo como una proyección sobre el espacio (acuciada en Nueva York), como paseante y como observador que solo podrá definirse por lo que no es, en donde no está. En ese juego de mirar para mirarse, de buscar(se) y encontrar(se) se ha podido observar una lucha constante con(tra) el espacio y el tiempo que somete a los narradores a su indeterminación. Vemos en ellas tres formas de la construcción de la consciencia del tiempo, como un pasado absoluto (Fractura), un futuro inminente (El rey recibe) y un presente continuo (Ventanas de Manhattan).

Las tres narraciones que han ocupado este artículo se construyen sobre un eje espaciotemporal conducido, no por la linealidad del tiempo y la estabilidad del espacio, sino por las rutas de la memoria y el olvido que trazan los paisajes de un yo reminiscente. Esta batalla acaecida en las tres novelas sobreviene de un primer golpe que, como telón de fondo, se entrevé en las narraciones en el arranque mismo los textos: la fragilidad de la existencia. El pánico nuclear de los 70 (retomado en 2011 en el seísmo de Fukushima), la incertidumbre post-dictatorial (con el atentado contra Carrero Blanco) y el atentado del 11S, funcionan como fuerzas desestabilizadoras del yo desamparado y huérfano, que tiene en el vacío su principal enemigo. En el intento de los protagonistas por sujetarse a la trascendencia temporal a través de un movimiento espacial, su discurso literario revela la permanente condena del sujeto extrańado, situado eternamente entre-textos, únicamente aprehendido como la proyección figurada en la imaginación y la memoria de la colectividad. Pues, dejando nuestro texto en manos de Quevedo que continúan los versos de aquel poema aludido por Muñoz Molina:

¡Oh Roma!, en tu grandeza, en tu hermosura

huyó lo que era firme, y solamente

lo fugitivo permanece y dura. 


\section{Obras CiTADAS}

Álvarez Méndez, Natalia. 2017. “Geografías de la memoria y otros territorios fabulados. Los espacios narrativos de Luis Mateo Díez y José María Merino”. Ana Casas y Ángeles Encinar. El arte de contar. Los mundos ficcionales de Luis Mateo Diez y José María Merino. Madrid: Cátedra. 133-155.

Aristóteles. "De memoria et reminicentia". Parva Naturalia. (Ed. J. A. Serrano, 1993). Madrid: Alianza Editorial.

Bajtín, Mijail. 1975. The Dialogic Imagination. Four Essays. (Ed. M. Holoquist, 1981). Texas, University of Texas.

Barthes, Roland. 1986. "Retórica de la imagen”. Lo obvio y lo obtuso. Barcelona: Paidós. 27-43. Baudrillard, Jean. 1978. Cultura y simulacro. Barcelona: Kairós.

Bergson, Henri. 2006. Materia y memoria: ensayo sobre la relación de cuerpo con el espiritu. Buenos Aires: Cactus.

Casas, Ana. 2012. La autoficción. Reflexiones teóricas. Madrid: Arcolibros.

Cervantes, Miguel de. 1605. Don Quijote de la Mancha (Ed. Conmemorativa RAE y ASALE, 2015). Barcelona: Alfaguara.

Colinas, Antonio. 2004. "La literatura de la memoria". Centro virtual Cervantes. Web.

Colmeiro, José. 2017. "Memoria, ideología y heterodoxia: Contra el pensamiento hegemónico". MVM: Cuadernos de Estudios Manuel Vázquez Montalbán 3.1: 3-24.

Díez, Luis Mateo. 2005. “Territorios de la imaginación y la memoria”. Jose María Balcells. Actas del II Congreso de Literatura Contemporánea. Burgos: Fundación Instituto Castellano y Leonés de la Lengua. 19-22.

Dubrovsky, Segre. 1977. Fils. París: Galilée.

Greenblatt, Stephen. 1992. Shakespearean negotiations: the circulation of social energy in Renaissance England. Oxford: Clarendon Press.

Grohmann, Alexis. 2011. Literatura y errabundia: Javier Marias, Antonio Muñoz Molina y Rosa Montero. New York: Rodopoi.

Jameson, Fredric. 1991. El posmodernismo o la lógica cultural del capitalismo avanzado. Barcelona: Paidós Ibérica.

Maldonado Alemán, Manuel. 2010. "Literatura, memoria e identidad: una aproximación teórica". Revista de Filología Alemana, Anejo 3: 171-179.

Mendoza, Eduardo. 1986. Nueva York. Barcelona: Ediciones Destino. 2018. El rey recibe. Barcelona: Seix Barral. . 2018b. "Entrevista". Libertad digital. Web.

Muñoz Molina, Antonio. 2004. Ventanas de Manhattan. Barcelona: Seix Barral. . 2004b. "Entrevista Babelia". El País. Web.

Nalbantian, Suzanne. 2003. Memory in literature. Palgrave Macmillan UK.

Neuman, Andrés. 2018. Fractura. Madrid: Alfaguara.

Pfeiffer, Michael. 1999. "Entrevista con Eduardo Mendoza”. El destino de la literatura: diez voces. Barcelona: El Acantilado. 125-142. 
Pozuelo Yvancos, José María. 1993. Poética de la ficción. Madrid: Síntesis. . 2010. Figuraciones del yo en la narrativa. Javier Marías y Enrique Vila-Matas. Valladolid: Cátedra Miguel Delibes. . 2012. "Figuración del Yo frente a autoficción". Ana Casas. La autoficción: reflexiones teóricas. Madrid: Arco Libros. 151-173.

. 2018a. "Fractura, en los paisajes desolados de Fukushima", 2018. ABC. Web . 2018b. "El rey recibe: la revolución del 68, según Eduardo Mendoza". $A B C$. Web.

Pratt, Mary Louise. 1986. "Ideology and speech-act theory”. Poetics today 7.1: 59-72.

Ricoeur, Paul. 2003. La memoria, la historia, el olvido. Madrid: Trotta.

Sánchez, Yvette. 1999. Coleccionismo y literatura. Madrid: Cátedra.

Savater, Fernando. 2017. La infancia recuperada. Madrid: Taurus.

Segre, Cesare. 1985. Principios del análisis del texto literario. Barcelona: Editorial Crítica.

Shklovsky, Víktor. 1970. "El arte como artificio". Tzvetan Todorov. Teoría de la literatura de los formalistas rusos. México: Siglo XXI Editores. 55-70.

Young, Sara, Nünning, Ansgar y Erll, Astrid. 2008. Cultural Memory Studies: An International and Interdisciplinary Handbook. Berlín: Walter de Gruyter. 